\title{
Evaluation of the correlation between the chemical profile and the antalgic and anti-proliferative activities of essential oil of Elionurus hensii K. Schum
}

\begin{abstract}
Aubin Nestor Loumouamou ${ }^{1,2 \star}$, Kévin Bikindou ${ }^{1,2}$, Hermeline Ntalani ${ }^{2}$, Thomas Silou ${ }^{1,4}$, Pierre Chalard $^{3,5}$, Ombeline Danton ${ }^{3,5}$, Laeticia Delort ${ }^{6,7}$, Caroline Decombat ${ }^{6,7}$, Florence CaldefieChezet $^{6,7}$, Cathérine Rubat-Coudert ${ }^{8}$ and Gilles Figueredo ${ }^{9}$
\end{abstract}

\footnotetext{
${ }^{1}$ Equipe Pluridisciplinaire de Recherche en Alimentation et Nutrition (EPRAN), Faculté des Sciences et Techniques, Université Marien Ngouabi, BP 389, Brazzaville, Congo.

${ }^{2}$ Institut National de Recherche en Sciences Exactes et Naturelles (IRSEN), Cité scientifique de Brazzaville, BP 2400, Congo.

${ }^{3}$ Université Clermont Auvergne, SIGMA Clermont, Institut de Chimie de Clermont-Ferrand, BP 10448, F-63000 Clermont-Ferrand, France.

${ }^{4}$ Ecole Supérieure de Technologie (EST-Cataractes), Brazzaville, Congo.

${ }^{5}$ CNRS, UMR 6296, Institut de Chimie de Clermont-Ferrand, F-63178 Aubière, France.

${ }^{6}$ Université Clermont Auvergne, Université d'Auvergne, UFR Pharmacie, UMR 1019, Unité de Nutrition Humaine, Equipe ECREIN, CLARA, Clermont-Ferrand, France.

${ }^{7}$ INRA, UMR 1019, Unité de Nutrition Humaine, CRNH Auvergne, Clermont-Ferrand, France.

${ }^{8}$ Université Clermont Auvergne, Université d'Auvergne, NEURO-DOL, BP 10448, F-63000 Clermont-Ferrand, France.

${ }^{9}$ Laboratoire d'analyse des Extraits végétaux et des Arômes (LEXVA), Biopole, Clermont-Limagne, Saint-Beauzire, France.
}

\begin{abstract}
Elionurus hensii is usually used by peasant populations as a théiforme drink to relieve aches. The aim of this study was to evaluate the antalgic activity (AA) and antiproliferative activity (ATA) of essential oil of Elionurus hensii (VEH). Essential oils from the aerial parts and roots was extracted by hydrodistillation and analyzed by GC and GC/MS. AA was examined by using test cramps. This method consists in inducing cramps in the mouse by intraperitoneal injection of $0.6 \%$ acetic acid solution and to determine any inhibition of these cramps by the compounds contained in the VEH. Cytotoxicity of the essential oil was evaluated in order to assess their ATA on cancer cells MCF-7 using resazurin test. The study was carried out by considering 6 samples of VEH whose contents of major compounds vary. The major constituents are $p$ menthadienol isomers and limonene for samples from the aerial part, aristolone and limonene for samples from the roots. The most significant AA (inhibition percentage $=56.41 \%$ ) was observed with a VEH containing $p$-menthadienol isomers $(40.25 \%)$ and limonene $(15.85 \%)$. The VEH containing limonene (20.21\%) and aristolone (15.16\%) also inhibit cramps with a percent inhibition of $48 \%$. The pure aristolone extract of the essential oil inhibits to $36 \%$. These first results confirm the traditional use of Elionurus hensii by peasant populations. The results of the resazurin test showed that the ATA is dose-dependent. VEH from roots, exhibited better anti-proliferative activity compared to the VEH from the aerial part. However, this activity is low.
\end{abstract}

Keywords: Elionurus hensii, essential oil, chemical compounds, GC/MS analysis, antalgic and antiproliferative activities. 


\section{INTRODUCTION}

Elionurus hensii belongs to the genus Elionurus which contains about twenty species already identified. In Congo-Brazzaville, the geographical distribution of this species seems to be restricted to the "plateau des cataractes" (80 km south of Brazzaville) where it grows spontaneously. This is a transition zone between the southern and the northern part of Congo, limited to the north by the "plateaux Batéké", to the southeast of congo river and DRC, to the west by the Ndouo (Niari) and to the northwest by the foothills of Chaillu massif (Bikindou, 2017). E. hensii is a perennial grass composed of culms 60 to $100 \mathrm{~cm}$ long, with strongly developed side branches forming blades 7 to $10 \mathrm{~cm}$ long, 2 to $3 \mathrm{~cm}$ wide that flower at maturity (Clayton et al., 2008). E. hensii is usually used by local people as a théiforme drink to relieve aches, which even justifies its vernacular name "tikoni". However, no scientific studies have been done to confirm these traditional practices.

This is the first study concerning the evaluation of the antalgic and antiproliferative activities of oils from $E$. hensii. The first explorations on the chemical composition showed that the essential oil from the aerial parts (stems and flowering tops) and roots of this species present two chemical profiles. The aerial part is rich in monoterpene alcohols which are the p-menthadienol isomers: cis- and trans-p-mentha-2,8-dien-1-ol, cis and trans p-mentha1(7), 8-dien-2-ol. The roots are rather rich in sesquiterpene compounds which the main component is aristolone (Silou et al., 2006). This chemical composition has been recently confirmed through a study of the seasonal variation of the chemical profile (Loumouamou et al., 2016, 2017). The essential oils of the species rich in p-menthadienol isomers present many biological properties. It is the case of Cymbopogon densiflorus and C. giganteus whose essential oils exhibit antimicrobial properties. Indeed, these species are the subject of many uses: the crushed leaves of $C$. densiflorus are used as a treatment for rheumatism in Gabon, the flower head is smoked in a pipe as a cure brochial affections in Malawi, and the plant sap is used in the Congo-Brazzaville as a treatment for asthma and calm fits (Menut et al., 2000; Boti et al., 2006; Akhila, 2010). Aristolone is also an interesting constituent since it is likely to induce an antalgic activity (Wu et al., 2004). The probable influence of the p-menthadienol isomers on the biological properties of these species has inspired the recent study on the optimization of the extraction of this components contained in the essential oil from $E$. hensii (Loumouamou et al., 2017).

Furthermore, the antioxydant activities of essential oils and solvent extracts of $E$. hensii from Congo-Brazzaville was studied (Yang et al., 2013). The essential oil did not exhibit significant antioxydant activity in terms of DPPH and $\mathrm{ABTS}^{+}$scavenging ability, and exhibited only slight $\mathrm{Fe}^{3+}$ reducing ability. However, the antioxydant activity of the solvent extracts was found important.

\section{MATERIALS AND METHODS}

\section{Plant material}

The plant material consists of the aerial parts (stems, leaves and flowering tops) and roots were collected on three sites: Loufoulakari (L) located at -4.4816 (latitude in decimal degrees), 14.9381 (longitude in decimal degrees), Campus rural (C) located at -4.4697 (latitude), 14.9450 (longitude) and Sese (S) located at -4.4125 (latitude), 14.6805 (longitude) and at different period of the year : February (f), May (m), June (j), November (n) and December (d). These harvest periods include periods of drastic reduction in rainfall (the dry season which covers the months of May and June) and periods of heavy rainfall (the rainy season which covers the months of November and December).

\section{Extraction of the essential oil}

Volatile extracts of $E$. hensii (VEH) has been obtained from dry plant by steam distillation using Clevenger type apparatus (Clevenger, 1928). Each time, $300 \mathrm{~g}$ of vegetable material, consisting either only of the roots or the aerial parts are placed in the plant tank above the balloon containing $500 \mathrm{ml}$ of water and subjected to distillation. The organic phase from the distillation is separated from the aqueous phase by extraction with diethyl ether. The organic phase is dried over anhydrous sodium sulfate to remove traces of water and the essential oil is recovered after evaporation of the diethyl ether and then submitted to the chromatographic analysis.

\section{GC analysis}

The quantitative analysis of the essential oil was carried out using an Agilent gas chromatograph model 6890 equipped with a DB5 column $(20 \mathrm{~m} \times 0.18 \mathrm{~mm} ; 0.18 \mu \mathrm{m})$. The oven temperature was programmed to $50^{\circ} \mathrm{C}$ for $3.2 \mathrm{~min}$, then heated to $300^{\circ} \mathrm{C}$ at a rate of $10^{\circ} \mathrm{C} / \mathrm{min}$. The temperatures of the injector and the flame ionization detector (FID) were maintained at $280^{\circ} \mathrm{C}$. The essential oils were diluted in acetone to $3.5 \%(\mathrm{v} / \mathrm{v})$ and injected in split mode $(1 / 60)$; hydrogen was used as the carrier gas $(1 \mathrm{ml} / \mathrm{min})$, and the injection volume was $1 \mu \mathrm{l}$. At the same time, a solution of $n$-alkanes (C8C30) was analyzed under the same conditions to calculate retention indices (RI) using the Van den Dool and Kratz equation (Van Del Dool and Kratz, 1963). The relative concentrations of the compounds were calculated from the peak area obtained by gas chromatography without using correction factors.

\section{GC/MS analysis}

Qualitative analysis was performed using an Agilent gas chromatograph model 7890 coupled to a Agilent mass spectrometer model 5975 equipped with a DB5 MS column $(20 \mathrm{~m} \times$ $0.18 \mathrm{~mm} ; 0.18 \mu \mathrm{m})$. The oven temperature was $50^{\circ} \mathrm{C}$ and remained constant for $3.2 \mathrm{~min}$; then, it was increased to $300^{\circ} \mathrm{C}$ at a rate of $8^{\circ} \mathrm{C} / \mathrm{min}$. The injector temperature was $280^{\circ} \mathrm{C}$. Ionization was obtained by electron impact at $70 \mathrm{eV}$, and the electron multiplier was maintained at $2200 \mathrm{eV}$. The temperature of the ion source was $230^{\circ} \mathrm{C}$. Mass spectral data were acquired in the scan mode in the range $\mathrm{m} / \mathrm{z} 33-450$. The flow of carrier gas (helium) was set at 0.9 $\mathrm{ml} / \mathrm{min}$. The identification of the compounds was made by comparison of their mass spectra and $\mathrm{RI}$ with those of libraries such as Adams (2012), NIST (2008), König et al. (2001) and those of laboratory. 


\section{Antalgic activity (AA)}

In order to verify the traditional practice of using $E$. hensii as theiforme drink to relieve pain, we have realized tests to evaluate the antalgic activity. The method used is that described by Collier et al. (1968) and Musa et al. (2008). This method, also called Writing test or test cramps, is still widely used (Gangwar et al., 2016). It consists of inducing cramps in the mouse by intraperitoneal injection of $0.6 \%$ acetic acid solution and to determine any inhibition of these cramps by the test compound. The pain is described as cramping and manifests itself in mice by a stretching movement of the hind legs and torsions of the dorsal-abdominal musculature.

The study was conducted at the Faculty of Pharmacy of the University of Auvergne (France) on male mice, in white color and swiss breed, weighing $30 \mathrm{~g}$. The animals were coming from the livestock JANVIER and arrived to the pet store of laboratory one week before the test, with a weight between 16 and $18 \mathrm{~g}$. The protocol was approved by the ethics committee for animal experimentation in Auvergne-France (No. record of this committee: C2E2A-O2).

The protocol implemented were composed of three batches of 8 mice distributed as follows: (i) the first batch had receive by gavage a solution of Tween 20 prepared in water for HPLC; (ii) the second batch had been treated with the essential oil at a dose of $100 \mathrm{mg} / \mathrm{kg}$ of body weight; (iii) the third batch had received the oral morphine at a dose of $1 \mathrm{mg} / \mathrm{kg}$ of body weight; $30 \mathrm{~min}$ after administration of the products, acetic acid prepared in the $0.6 \%$ of physiologic salt solution $(0.3 \mathrm{ml} / \mathrm{kg})$ is injected to mice by intraperitoneally. The number of cramps had been counted for $20 \mathrm{~min}$. The antalgic activity was estimated as percent inhibition cramps by the following formula:

$\% \mathrm{I}=[$ (Average number of cramps in the control batch - average number of cramps in the test batch) / (average number of cramps in the control batch) $] \times 100$.

All the data of control and treated animals were analyzed using the student $t$-test, further the significance difference $(P$ values $<0.01$ ) was calculated between mean values. The values expressed after the analysis were average \pm standard error of means (SEM).

\section{Antiproliferative activity (ATA)}

Cytotoxicity assays were conducted at the Laboratory of Plant Sciences and pharmaceutical Fungal EA 4233 team «Nutrition Carcinogenesis and therapy antitumorale» of the Faculty of Pharmacy of Auvergne University. The ATA was assessed using the resazurin reduction test as described by O'Brien et al. (2000). The tests were carried out on cancer cells of human breast adenocarcinoma MCF-7 (ATCC-HTB-22). According to the cells growth profile, MCF-7 cells were seeded into the wells of microplates at a concentration of $50,000 \mathrm{cells} / \mathrm{ml}$. The microplates were kept in an incubator at $37^{\circ} \mathrm{C}$, in an humidified atmosphere containing $5 \%$ carbon dioxide. After $24 \mathrm{~h}$, the cells were treated with the VEH initially dissolved in dimethylsulfoxide (DMSO). In parallel, for each tested essential oil, a control of DMSO (solvent of dilution of the EO) is produced. Plates were returned into the incubator for $72 \mathrm{~h}$ under the same conditions. After this final period of incubation, the culture medium was replaced with a solution of resazurin $(25 \mathrm{mg} / \mathrm{ml})$ which in the presence of metabolically active cells is oxidized into resorufin, fluorescent at $590 \mathrm{~nm}$. The intensity of fluorescence was proportional to the number of viable cancer cells. Fluorescence was then measured using a plate reader (Fluoroskan Ascent ${ }^{\mathrm{R}} \mathrm{FL}$. Thermo Electron Corporation France) at $590 \mathrm{~nm}$.

ATA was evaluated using the following concentration ranges: $0.04 \%(372 \mu \mathrm{g} / \mathrm{ml}), 0.02 \%(186 \mu \mathrm{g} / \mathrm{ml})$ and $0.01 \%(93 \mu \mathrm{g} / \mathrm{ml})$ for essential oil and 10, 25, 50 and $100 \mu \mathrm{g} / \mathrm{ml}$ for aristolone. The intensity of fluorescence obtained after reading with Fluoroskan Ascent (expressed in arbitrary units) was converted into percentage of inhibition of proliferation relative to cells proliferation in the control (DMSO). It was established that DMSO got no influence on cell proliferation, in comparison with a control performed without DMSO under the same conditions.

\section{RESULTS AND DISCUSSION}

\section{Chemical composition of the volatile extracts studied}

VEH involved in this study are from the aerial parts $(\mathrm{Cd}$, $\mathrm{Sm}$ and Ln) and roots (Cf, Ln and Sn). The VEH of the aerial part are rich in $\mathrm{p}$-menthadienol isomers, the overall content is of the order of $40 \%$. The contents of cis- and trans-p-mentha-1(7), 8-dien-2-ol (23 to 39\%) are twice as high as those of the cis- and trans-p-mentha-2,8-dien-1-ol (10 to $16 \%$ ). These contents are also found in the same proportions in the essential oil of $C$. giganteus (Menut et al., 2000 ; Boti et al., 2006): cis- and trans-p-mentha1(7),8-dien -2-ol (31.7 to 49.3\%) cis- and trans-p-mentha2,8-dien-1-ol (26.7 to $27.6 \%$ ). However, in the essential oil of $C$. densiflorus the content of cis-p-mentha-1(7),8dien-2-ol $(11.1 \%)$ is low and that of trans-p-mentha-2,8dien-1-ol $(22,4 \%)$ is greater (Chisowa, 1997). The limonene is the other major constituent. In the Sm VEH the content of limonene is low (2\%), but it is higher in the VEH of Cd and Ln (15.85 and 19.28\%, respectively). Concerning the essential oil from the roots, the aristolone and the limonene are the two main major constituents. The Cf and Sn VEH are rather rich in aristolone (44.55 and $32.29 \%$, respectively) whereas the Ln VEH is rich in the limonene (30.44\%). It should be noted that the essential oil of the roots of Elionurus muticus is much richer in aristolone $(72.1 \%)$ than that of Elionurus hensii (Chagonda et al., 2012). The complete chemical composition of the six VEH is presented in Table 1.

\section{Antalgic activity}

The AA of VEH from the aerial part and the roots of Elionurus hensii was evaluated by considering 6 samples whose chemical profile in major constituents are presented in Table 1. Analysis of the results shows that mice treated with $\mathrm{VEH}$ reducing significantly cramps caused by the injection of acetic acid, compared to the control group. The average number of cramps recorded for samples $\mathrm{Cd}, \mathrm{Sm}$, and $\mathrm{Ln}$ is respectively 20.13, 24.00 and 29.88, which corresponds to a percentage of inhibition respectively of $56.41,41.83$ and $35.29 \%$ (Figure 1). The t-test values of student $(p<0.05)$ are respectively $5.49,2.33$ and 2.30 , the theoretical t-test is 2.16. One should note that morphine, which is the reference, exhibits a number of means cramps equal to 13.75 $(70.22 \%)$. The antalgic effect is more important for sample $\mathrm{Cd}$ because it significantly inhibits cramps. The 
Table 1. Chemical composition of the VHE.

\begin{tabular}{|c|c|c|c|c|c|c|c|}
\hline \multirow{2}{*}{ Components } & \multirow{2}{*}{$\mathbf{R I}$} & \multicolumn{3}{|c|}{ Aerial part } & \multicolumn{3}{|c|}{ Roots } \\
\hline & & $\mathrm{Cd}^{*}$ & $\mathrm{Sm}$ & $\operatorname{Ln}$ & $\mathrm{Cf}$ & Ln & Sn \\
\hline Tricyclene & 922 & 0.37 & 0.41 & 0.35 & 0.80 & 0.35 & 0.23 \\
\hline$\alpha$-thujene & 925 & - & - & - & 0.22 & 0.22 & - \\
\hline$\alpha$-pinene & 933 & 0.27 & - & 0.25 & 1.45 & 0.78 & 0.4 \\
\hline camphene & 950 & 1.16 & 6.07 & 1.25 & 2.57 & 1.24 & 0.88 \\
\hline Sabinene & 973 & - & & 0.05 & 0.27 & 0.21 & - \\
\hline myrcene & 989 & 0.31 & & 0.48 & 0.61 & 1.05 & 0.77 \\
\hline ortho-cymene & 1025 & & 1.82 & 0.95 & 0.35 & 1.11 & 0.70 \\
\hline limonene & 1028 & 15.85 & 2.09 & 19.28 & 8.75 & 30.44 & 18.41 \\
\hline 1.8-cineole & 1032 & & 0.21 & - & 2.61 & 4.51 & 2.48 \\
\hline Terpinolene & 1085 & & - & 0.06 & & 0.27 & 0.17 \\
\hline trans-p-mentha-2,8-dien-1-ol & 1125 & 10.65 & 6.16 & 16.22 & 0.19 & 2.15 & 0.89 \\
\hline cis-p-mentha-2,8-dien-1-ol & 1137 & 5.84 & 4.56 & 6.39 & 0.13 & 1.63 & 0.62 \\
\hline Pinocarvone & 1163 & 0.17 & 0.51 & 0.20 & & 0.25 & - \\
\hline Terpinen-4-ol & 1182 & & - & 1.73 & 0.20 & - & \\
\hline trans-p-mentha-1(7),8-dien-2-ol & 1192 & 11.02 & 20.16 & 12.89 & 0.42 & 3.49 & 2.80 \\
\hline trans-carveol & 1221 & 6.65 & 7.5 & 1.83 & 0.15 & 1.6 & \\
\hline cis-p-mentha-1(7),8-dien-2-ol & 1230 & 12.74 & 19.01 & 13.52 & 0.34 & 3.23 & 2.19 \\
\hline cis-carveol & 1233 & 0.74 & & 5.36 & - & & \\
\hline carvone & 1245 & 3.34 & 4.49 & 3.45 & 0.15 & 1.28 & 0.90 \\
\hline piperitone & 1255 & 1.47 & 0.61 & 0.41 & 0.27 & 1.02 & 0.64 \\
\hline Undecan-2-one & 1292 & 2.98 & 9.03 & 3.52 & 0.80 & 6.20 & \\
\hline$\alpha$-gurjunene & 1412 & 2.3 & - & - & 0.98 & - & - \\
\hline$\beta$-gurjunene & 1435 & - & - & 0.14 & 9.98 & 4.71 & 4.43 \\
\hline Tridecan-2-one & 1495 & 1.96 & 5.5 & 1.97 & & 2.60 & 2.34 \\
\hline Nerolidol <E> & 1561 & 2.3 & - & 0.28 & & - & 0.60 \\
\hline maaliol & 1575 & - & - & - & 2.51 & 1.83 & - \\
\hline intermedeol & 1671 & 0.82 & 2.9 & 3.19 & 1.6 & 3.03 & 5.91 \\
\hline aristolone & 1764 & 0.41 & - & 0.6 & 44,55 & 14.08 & 32.29 \\
\hline Total p-menthadienol isomers (\%) & & 40.25 & 49.89 & 49.02 & 1.08 & 10.5 & 6.5 \\
\hline
\end{tabular}

${ }^{*} \mathrm{Cd}$ : campus-december; Sm: sese-may; Ln: loufoulakari-november.

Cf: campus-february; Sn: sese-november.

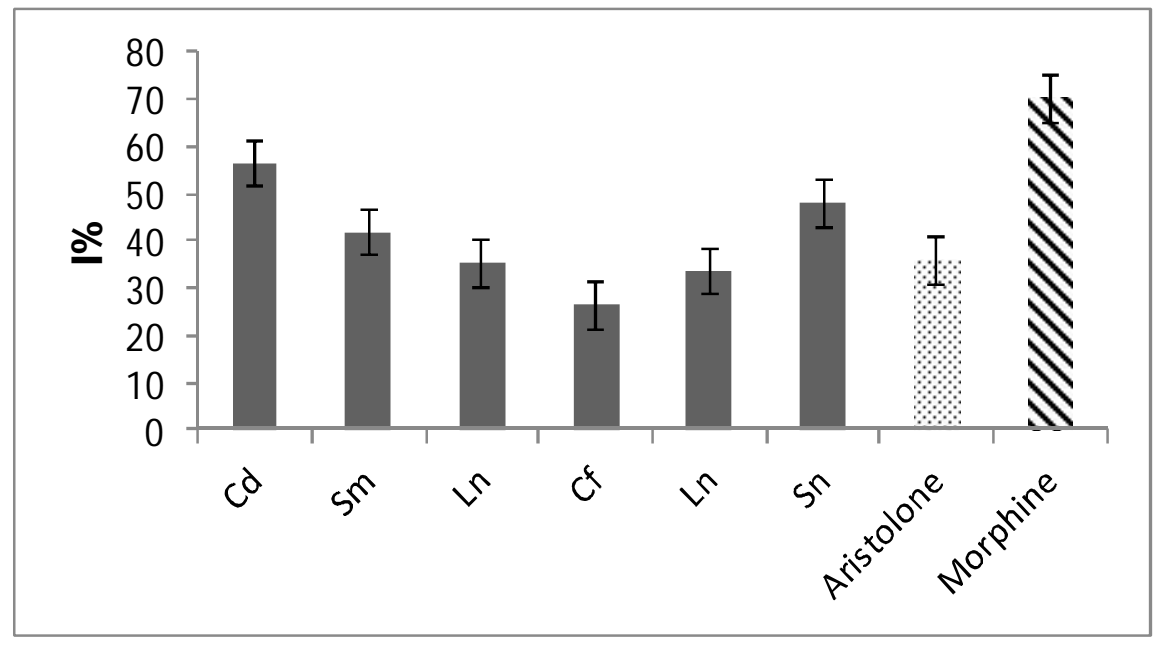

Figure 1. Inhibition percent of $\mathrm{VEH}$, aristolone and morphine. 
other two samples (Sm and $\mathrm{Ln}$ ) also present a real inhibition, but moderate (the t-test values are low).

At the roots level, four samples of VEH was tested: three VEH (Cf, Sn and Ln) and one sample of the aristolone resulting from the splitting of VEH. The results holistically show a low average number of cramps for essential oil samples compared to the witness. Sn, Ln and Cf VEH inhibit cramps respectively with 48, 33.57 and $26.35 \%$. This inhibition is significant with Sn sample because his t-test is equal to $3.29(p<0.05)$ and not significant for samples $\mathrm{Ln}$ and $\mathrm{Cf}$ with the t-test values equal to 2.20 and 1.05 (theoretical t-test is 2.16). The aristolone produced an average number of cramps equal to 40.33 with an inhibition percentage of $36 \%$, the t-test value is 4.02 . At a dose of $13 \mathrm{mg} / \mathrm{kg}$ (body weight), aristolone significantly inhibits abdominal cramps. The aristolone shows a real antalgic effect, but low compared to that of Sn VEH.

Comparing these results with those of the essential oil of Ageratum conyzoïdes, a species of the Congolese flora used in African traditional medicine for headaches and whose antalgic effect has been scientifically demonstrated (Abena et al., 1995, 1997), it turns out that the results obtained from the VEH are very promising.

\section{Anti-proliferative activity}

The ATA from the aerial part and the roots of Elionurus hensii was evaluated by considering $6 \mathrm{VEH}$ (the same samples considered for AA). The VEA of the roots is slightly found more active than that of the aerial part. Samples $\mathrm{Cd}, \mathrm{Sm}$ and $\mathrm{Ln}$ showed little anti-proliferative activity against MCF-7 cells. The samples $\mathrm{Sn}\left(\mathrm{IC}_{50}=\right.$ $244.45 \mu \mathrm{g} / \mathrm{ml})$, Cf $\left(\mathrm{IC}_{50}=244.3 \mu \mathrm{g} / \mathrm{ml}\right)$ and aristolone $\left(\mathrm{IC}_{50}=37.77 \mu \mathrm{g} / \mathrm{ml}\right)$, from roots, exhibited better antiproliferative activity compared to $\mathrm{VEH}$ from the aerial part. The results show that the inhibition of MCF-7 cells is very important when the concentration is high: the ATA is dose-dependent (Figure 2). This activity can be justified by the fact that the samples from the roots are rich in sesquiterpene compounds such as aristolone (Wu et al., 2004; Shi et al., 2009) and intermedeol (Ercil et al., 2001).

Indeed, it seems that the high content in aristolone of essential oil from roots is largely responsible for the observed activity. Furthermore, the very low activity observed with essential oil can find the explanation in a potential antagonistic effect between the different constituents of the essential oil.
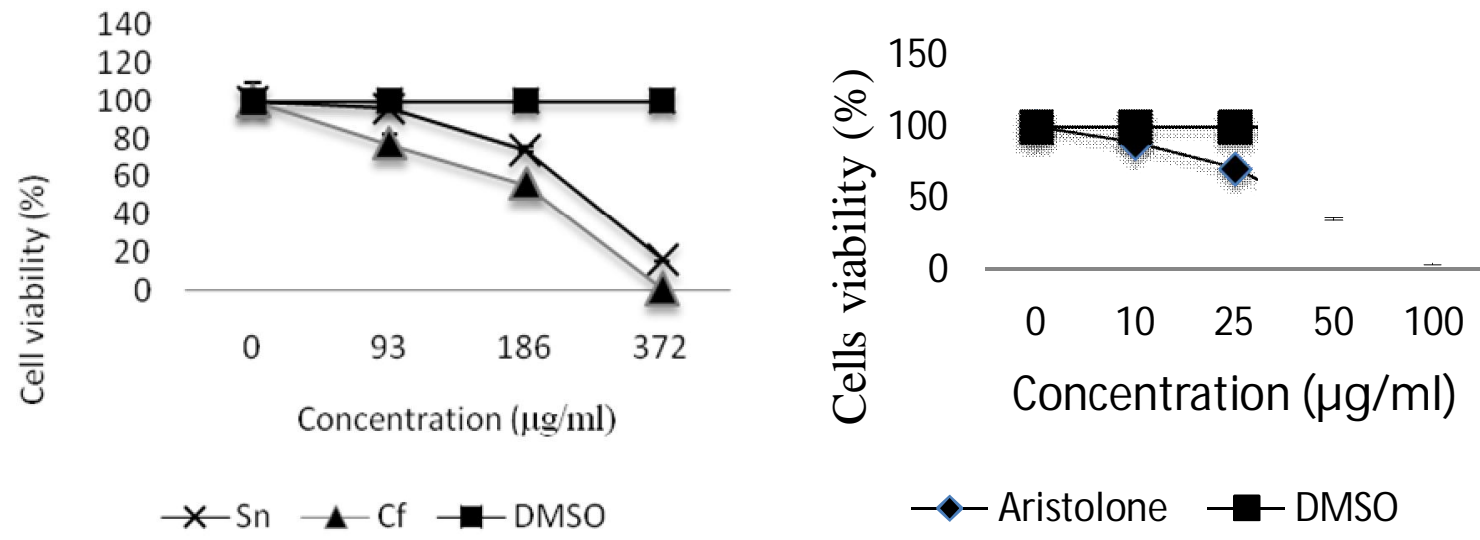

Figure 2. Dose-dependent anti-proliferative activity of essential oil and aristolone.

\section{CONCLUSION}

This study showed very interesting and promising results on the antalgic activity of the analyzed VEH. For the aerial part, the most significant antalgic effect (inhibition percentage $=56.41 \%$ ) was observed with a VEH containing trans-p-mentha-2,8-dien-1-ol (10.65\%), cis-pmentha-2,8-dien-1-ol (5.84\%), trans-p-mentha-1(7),8dien-2-ol (11.02\%), cis-p-mentha-1(7),8-dien-2-ol (12.74\%), trans-carveol (6.65\%) and limonene (15.85\%). Concerning the roots, the VEH containing $20.21 \%$ of limonene and $15.16 \%$ of aristolone inhibit significantly cramps with an inhibition percentage of $48 \%$. The aristolone resulting from the splitting of VEH inhibits to $36 \%$. These first results show a real antalgic effect of $\mathrm{VEH}$, which makes it possible to validate the use of Elionurus hensii by local people for to relieve aches. It would be interesting to deepen the studies on VEH to better understand the correlation between the chemical composition and the antalgic activity and to identify the molecules responsible for this activity. The ATA from the aerial part and the roots of Elionurus hensii is low. The essential oil of the roots is slightly found more active than that of the aerial part. This difference activity observed may be largely due to the presence of sesquiterpenes which predominate in the essential oil of the roots. 


\section{ACKNOWLEDGEMENT}

The authors will like to address the greatest consideration to the French cooperation at Congo and to Marien Ngouabi University of Brazzaville (Congo) for financial support.

\section{REFERENCES}

Abena AA, Kibori DP, Bioka D, 1995. Propriétés antalgiques et antipyretiques de l'huile essentielle d'Ageratum conyzoïdes. Pharm Med Trad Afr, pp. 67-72.

Abena AA, Ouamba JM, Keita A, 1997. Activités anti-inflammatoire, antalgique et antipyrétique de l'huile essentielle de Ageratum conyzoïdes. Pharm Med Trad Afr, 9: 48-55.

Adams RP, 2012. Identification of essential oils by capillary gas chromatography/mass spectroscopy. Allured, Carol stream, IL.

Akhila A, 2010. Chemistry and Biogenesis of Essential Oil from the Genus Cymbopogon. In Essential oil Bearing Grasses. The genus Cymbopogon. CRC Press. Taylor and Francis Group, LLC.

Bikindou K, 2017. Caractérisation physico-chimique et évaluations des activités biologiques de Elionurus hensii K. (Schum) du plateaux des cataractes au Congo-Brazzaville. Thèse de doctorat. Université Marien Ngouabi. Brazzaville. Congo. Mai 2017.

Boti JB, Muselli A, Tomi F, Koukoua G, N'Guessan TY, Costa J, Casanova J, 2006. Combined analysis of Cymbopogon giganteus Chiov. Leaf oil from Ivory Coast by GC/RI, GC/MS and ${ }^{13} \mathrm{C}-\mathrm{NMR}$ C.R. Chimie, 9: 164-168.

Chagonda LS, Chalchat JC, Bessiere JM, 2012, Constituents of root essential oil of cultivated Elyonurus muticus (Spreng.) Kunth from Zimbabwe. Anal Chem Lett, 2: 177-181.

Chisowa BH, 1997, Chemical composition of flower and leaf oils of Cymbopogon densiflorus Staps from Zambia. J Essen Oil Res, 9: 469-470.

Clayton WD, Harman KT, Williamson H, 2008. Grass Base - The online world grass flora. http://www.kew.org/data/grasses$\mathrm{db} / \mathrm{www} / \mathrm{gen} 00603 . \mathrm{htm}$.

Clevenger JF, 1928. Apparatus for the determination of volatile oil. $J$ Am Pharm Assoc, 17: 341-346.

Collier OJ, Dinneen LC, Johnson C, 1968. The abdominal constriction response and its suppression by analgesic drugs in the mouse. $\mathrm{Br} J$ Pharmacol Chemother, 32: 295-310.

Ercil D, Ulusu NN, Sakar MK, 2001. The inhibitory effect of intermedeol on soybean lipoxygenase and its cytotoxicity. Turk Biyokimya Dergisi Cilt, 26: 2.

Gangwar M, Gautam MK, Ghildiyal S, Nath G, Goel RK, 2016. Pharmacological evaluation of Mallotus philippinensis (Lam.) Muell.Arg. fruit hair extract for anti-inflammatory, analgesic and hypnotic activity. J Intercult Ethnopharmacol, 5(1): 14-21.

König WA, Hochmuth DH, Joulain D, 2001. Terpenoids and Related Constituents of Essential Oils. Library of Mass Finder 2.1. Institue of Organic Chemistry, Hamburg.

Loumouamou AN, Bikindou K, Bitemou E, Chalard P, Silou T, Figueredo $G, 2017$. Optimization of the extraction of the $p$ menthadienol isomers and aristolone contained in the essential oil from Elionurus hensii using a $2^{3}$ full factorial design. Food Sci Nutr, 5(3): 784-792.

Loumouamou AN, Bikindou K, Silou T, Chalard P, Figueredo G, 2016. Essential oil of Elionurus hensii (Schum) from "Plateau des Cataractes" in Congo Brazzaville: variation of the chemical composition and evaluation of the antioxidant activity. Adv J Food Sci Technol, 12(12): 709-718.

Menut C, Bessiere JM, Samate D, Djibo AK, Buchbauer G, Schopper $B$, 2000. Aromatic plants of tropical west Africa XI. Chemical composition, antioxidant and antiradical properties of the essential oils of three Cymbopogon species from Burkina Faso. J Essent Oil Res, 12: 207-212.
Musa YM, Haruna AK, liyas M, Yaro AH, Ahmadu AA, Usman H, 2008. Phytochemical, analgesic and anti-inflammatory effects of the ethylacetate extract of the leaves of Pseudocedrella kotschyii. Afr $\mathrm{J}$ Trad Complement Altern Med, 5(1): 92-96.

National Institute of Standards and Technology (NIST), 2008. Spectral Database for organic Compounds. NIST WebBook: http//webbook.nist.gov/chemistry.

O'Brien J, Wilson I, Orton T, Pognan F, 2000. Investigation of the Alamar Blue (résazurine) fluorescent dye for the assessment of mammalian cell cytotoxicity. Eur J Biochem, 267: 5421-5426

Shi YC, Zhi HW, Shang KW, Michael YC, Ali AHEG, Chang FD, Chang $Y D, 2009$. Revision of the absolute configuration at $C(23)$ of lanostanoids and isolation of secondary metabolites from formosan soft coral Nephthea erecta. Chem Biodivers, 6: 86-95.

Silou T, Loubaki L, Figueredo G, Chalchat JC, 2006. Study of essential oil composition of Elionurus hensii Schum from Congo. J Essent Oil Res, 18, 518-520.

Van Del Dool H, Kratz PD, 1963. A generalization of the retention index system including lenear temperature programmed gas-liquid partition chromatography. J Chromatograph, 11:463-471.

Wu T, Damu AG, Su C, Kuo P, 2004. Terpenoids of Aristolochia and their biological activities. Nat Prod Rep, 21: 594-624.

Yang Y, De Cian MC, Nsikabaka S, Tomi P, Silou T, Costa J, Paolini J, 2013. Volatile fraction composition and total phenolic and flavonoid contents of Elionurus hensii-Antioxidant activities of essential oils and solvent extracts. Nat Prod Commun, 8(5): 655-661.
Citation: Loumouamou AN, Bikindou K, Ntalani H, Silou T, Chalard P, Danton O, Delort L, Decombat C, Caldefie-Chezet F, RubatCoudert C, Figueredo G, 2017. Evaluation of the correlation between the chemical profile and the antalgic and anti-proliferative activities of essential oil of Elionurus hensii K. Schum. Adv Med Plant Res, 5(3): 41-46. 